\title{
Social Anxiety of Youth Prisoners and Guidance and Counseling Services for Prevention
}

\author{
Alizamar, Miftahul Fikri, Afdal \\ Jurusan Bimbingan dan Konseling FIP, Universitas Negeri Padang \\ email: afdal@konselor.org
}

(Diterima: 11-Oktober-2017; direvisi: 05-November-2017; dipublikasikan: 27-Desember-2017)

\begin{abstract}
Abstrac: Various juvenile delinquencies today lead them to the realm of law so they go to jail. The government has sought to provide coaching for juvenile inmates so that they are ready to enter new life once free, but the coaching that has been implemented has not been able to optimally reduce the problems of juvenile inmates. One of the problems that juvenile inmates face is the feeling of excessive fear and anxiety unacceptable in the social environment after being released from prison, which is also called social anxiety. For that, it takes a variety of understanding and appropriate programs to overcome social anxieties of juvenile inmates who can be done through counseling and counseling services This paper discusses the basic concepts of social anxiety and the importance of counseling and guidance services.
\end{abstract}

Keywords: Social Anxiety; Young Prisoners; and Guidance and Counseling Service

\begin{abstract}
Abstrak: Berbagai kenakalan remaja sekarang ini membuat mereka berhadapan dengan hukum hingga masuk penjara. Pemerintah telah berupaya memberikan pembinaan bagi narapidana remaja sehingga mereka siap untuk memasuki kehidupan baru setelah bebas, namun pembinaan yang telah dilaksanakan belum mampu secara optimal mengurangi berbagai masalah narapidana remaja. Salah satu masalah yang dialami narapidana remaja adalah perasaan takut berlebihan dan cemas tidak dapat diterima di lingkungan sosial setelah bebas dari penjara, yang disebut juga dengan kecemasan sosial. Untuk itu, dibutuhkan berbagai pemahaman dan program yang sesuai untuk mengatasi kecemasan sosial narapidana remaja yang bisa dilakukan melalui layanan bimbingan dan konseling Makalah ini membahas konsep dasar kecemasan sosial dan pentingnya layanan bimbingan dan konseling untuk mencegah kecemasan sosial pada narapidana remaja.
\end{abstract}

Kata Kunci : Social Anxiety; Narapidana Remaja; dan Pelayanan BK

Copyright ( 92017 Universitas Negeri Makassar. This is an open access article under the CC BY-NC-ND license (http://creativecommons.org/licenses/by-nc-nd/4.0/).

\section{INTRODUCTION}

The development of science and technology not only give a positive impact, but also bring up various negative impacts, either directly or indirectly impacts. These negative impacts include increased crime caused by the desire to follow the trend of technological progress. Current crime trends not only occur in adults in general but also occur in adolescents in general. The problem of crime was initially caused by the increasing of quality and quantity of juvenile delinquency and the happening of change/degradation of adolescent moral values which increasingly worried (Puspitawati, 2006). Adolescents may experience a variety of irregularities and criminal acts because at this time adolescents are still considered unstable and experienced a variety of major changes in physical, cognitive, and psychosocial aspects. Experts point out that as a result of the changes 


\section{1 | Jurnal Psikologi Pendidikan \& Konseling Vol. 3 No. 2 Desember 2017}

and developments they are experiencing, it is not uncommon for teenagers to fall in the negative direction, where they take actions they should not do, or do the deviant behavior (Chaplin, 2011; Papalia, Olds \& Feldman, 2009, Santrock, 2007). Deviant behavior perpetrated by teenagers can result in a violation of the law. According to the Penitentiary Database System in July 2017 there were 2,219 juvenile offenders in Indonesia, with an increase of $71.52 \%$ of prisoners at the Institute for Special Education for Children (LPKA) Class II in Tanjungpati District 50 Kota Provinsi West Sumatra.

Terms relating to criminal offenses for juveniles violating the law are regulated in Law Number 11 the Year 2012 on the Criminal Justice System of the Child. The explanation of the law indicates that citizens who commit crimes, aged 12-18 years, are still categorized as children and receive special treatment as in the juvenile justice system, and other special treatment. Age limits set forth by law psychologically can be said by adolescence, where further if they are sentenced for their deeds referred to as Adolescent Prisoners.

Although a teenager is already in prison, it is possible that once free he will become a useful person in society later on. The law suggests that juvenile inmates are fostered through the Institute for Special Education of Children (LPKA) so as not to do the same in the future.

Regulation of the Minister of Justice and Human Rights No. 18 of 2015 on the Organization and Working Procedures of the Special Child Development Institution (Lembaga Pendidikan Khusus Anak---LPKA) articles 3 and 4, states that: LPKA has the duty of conducting the guidance of protégés. Essentially, LPKA aims to restore the unity of life, life, and livelihood of adolescents dealing with the law. Despite special handling for juvenile inmates, life inside the prison affects the physical and psychological of everyone in it. Based on interviews with one of the builders at LPKA class II Tanjungpati on July 20, 2017, it is known that there are repeated guards who undergo a criminal time in detention due to the same violation cases. Many of the things that cause these problems occur, among them: their education is disconnected, thus causing the lack of information they get; then from the psychic condition of the inmates is different from their previous situation, which creates negative feelings towards themselves and avoids social situations that occur after freedom, this indicates that guidance programmed in LPKA such as personality coaching, independence coaching, education coaching has not provided readiness for juvenile inmates to face a more recent life after being free later on.

One of the problems that occur in adolescents who are being built in LPKA is social anxiety or social anxiety when it will be free. According to Nichols (in Yousaf, 2015: 140) social anxiety is "fear of being judged and evaluated negatively by other people, leading to feelings of inadequacy, inferiority, embarrassment, humiliation, and depression". Further Kearney (2005) describes social anxiety as a strong physiological passion in social situations involving possible evaluation by others, accompanied by anxiety or fear of psychological danger and the desire to escape or avoid social situations. Similarly, the Diagnostic and Statistical Manual of Mental Disorder (in Sagalakova, Truevtsev, \& Sagalakov, 2016) defines social anxiety disorder as a disorder that makes a person feel scared, anxious and avoids in social interaction situations such as: focusing more on self-attention when dealing with other people. So social anxiety or social anxiety is the fear and excessive fear of juvenile inmates leading to avoidance behavior in situations of social interaction, focusing on self-attention, and avoiding doing activities in front of others. Results of research conducted Sagalokova Truevtsev, \& Sagalakov (2016) found that from 7 to $16 \%$ of the population in modern western societies have symptoms of social anxiety.

Based on the phenomenon and reality described earlier, it is necessary a special strategy that can be used in alleviating the problems faced by juvenile inmates, especially to reduce social anxiety when it will be free. One of the services provided is guidance and counseling. Counseling and counseling of inmates (prisoners of youth) serve to overcome excessive fear inmates by fostering psychological preparedness and resilience when they are faced with conditions when they are in prison and after they leave (Fitria, 2012). Similarly, Yusri (2015) stated that in an effort to help the prisoners of prison correctional institutions are expected to make a policy in conducting a conducive coaching approach by providing guidance and counseling services to the recidivism for the development of personality and independence so 
that they can become useful individuals in the community and do not repeat the same mistake again. This indicates that Guidance and Counseling services have an important role for inmates in this case to reduce the social anxieties of juvenile inmates.

\section{Social Anxiety}

Anxiety is defined by Nevid, Rathus \& Greene (2005) as a state of apprehension or a state of worry for something bad will happen. Further Chaplin (2011) describes anxiety as an unpleasant, emotional state accompanied by a physical sensation of a person approaching danger or coming. Anxiety is associated with differences in how individuals produce representative psychic movements (Brown \& Stopa, 2008). Along with that Aqib (2013) defines anxiety as a manifestation of various mixed emotional processes, which occur when people are experiencing feelings of stress, frustration, and conflict. From the above opinion can be concluded anxiety is an emotional worry state by complaining that something bad will happen.

Many things to worry about in life such as health, social, career, and environmental conditions are a source of concern. Anxiety can be said to be normal and beneficial if there is no threat, but anxiety can become abnormal when the level is not appropriate to the threat, such as anxiety to interact with new people, avoid self from others for no apparent reason, this is categorized as social anxiety (Nevid, Rathus \& Greene, 2005). Bandelow \& Stein (2004) defines social anxiety with the most distressing fears and circumstances in social situations. Clark \& Beck (2010) someone with social anxiety convinces when he works with his partner will think it is not competent if he appears to speak. Social anxiety can be confused with strong depression, suicidal behavior, drug use, and behavior not to go to school (Kearney, 2005). Further, according to Abdollahi, Talib, Mobarakeh, Momtaz, \& Mobarake (2015), social anxiety presents the symptoms of shame, humiliation, and attention from negative judgments by others in social situations, and contemplation of social relationships and the tendency to withdraw from social activities. Social anxiety also depicts individuals who have fears continually performing in one or more social or performance situations (Bakalim, 2016). Based on the above opinion social anxiety can be summed up as the constant fear of one or more social situations where it can cause shame, depression and tend to withdraw in social situations.

Social anxiety is a problem that often occurs in adolescents, this will hamper the stage of optimal development, especially on social development (Kearney, 2005). Teenagers with this condition have fear, however, they will embarrass themselves when interacting with others (Root, 2000). People with social anxiety disorders generally recognize the nature of their excessive fear, but their lives are significantly impaired (Damer, Latimer, \& Porter, 2010). Further Carney \& Edinger (2010) symptoms of social anxiety can be from; avoiding the dreaded social situations, feelings of shame, physiological changes (eg, flushed face), and fear of being the center of attention. This will all happen to people who experience social anxiety within themselves.

Furthermore, the social anxiety symptoms can be categorized as somatic symptoms characterized by red face due to embarrassment, sweating, palpitations, distressed stomach and panic (Bandelow \& Stein, 2004; Nevid, Rathus \& Greene, 2005; Kearney , 2005), cognitive symptoms characterized by unpleasant thoughts on circumstances (Bandelow \& Stein, 2004; Mawandha \& Ekowarni, 2017), and behavioral symptoms that show attempts to hide reactions, difficulty speaking, avoid eye contact, anxiety, and avoidance a frightening situation (Bandelow \& Stein, 2004: 2).

Social anxiety affects the decrease in subjective well-being and quality of life, as well as social role functioning and career development (Wittchen \& Fehm, 2003). Furthermore, Greaca \& Lopez (in Festa \& Ginsburg, 2011) discloses adolescents with high levels of social anxiety reporting if they have fewer friends. High social anxiety will tend to cause; a) anxious responses such as cold sweat, trembling etc., b) difficulty communicating like a stutter, forgetting to say appropriate sentences or not being able to say what they think, c) avoiding contact with social situations both physically and psychological (avoidance behavior) such as little talk, little eye contact, or withdrawal, high social anxiety in adolescents avoid the social situations that cause them distress (Biggs, Vernberg, \& $\mathrm{Wu}, 2012$ ), and d) the covering behavior the impression of self (self-image) will disability (Nainggolan, 2011). 


\section{Young Prisoners}

Adolescents come from adolescere or adolentia which means to grow or grow into adulthood. Adolescence is one of the stages or phases of human development. During adolescence, adolescents experience many changes and developments, not infrequently teenagers fall into the negative direction, where they perform actions they should not do or behave deviant. This deviant behavior can be regarded as a child delinquency defined by Sarwono (2012) as the act of an immature person who deliberately violates the law and known by the child himself that the act was briefly known by the law officer he may be subject to punishment. Children who commit offenses that violate the law are regulated in Law Number 11 the Year 2012 regarding the Child Criminal Justice System whose contents, citizens who commit crimes, aged 12-18 years, are still categorized as children and receive special treatment as in the judicial system children, and other special treatment. Age restrictions put forward by law psychologically can be said by adolescents, who furthermore if they are sentenced for their deeds are referred to as juvenile inmates. So the teenagers who say juvenile inmates of children aged 12-18 years who commit a crime and have been sentenced.

Although in the course of the criminal trial at LPKA, the teenagers who are dealing with the law are entitled to obtain the rights that are part of it. In Act Number 12 of 1995 on Correctional Institutions, Article 14 specifies that inmates in this case juvenile inmates are entitled; a. perform worship according to religion or belief, b. received care, both spiritual and physical care, c. get education and teaching, d. get coaching, e. obtain appropriate health and food services, f) submit a complaint, g. obtain reading material and follow other mass media broadcasts that are not prohibited, $h$. receive family visits, legal counsel, or other specific persons, i. get the criminal reduction (remission), j. get an assimilate opportunity including family visiting leave, $\mathrm{k}$. get parole, $\mathrm{l}$. get free before leaving, and $\mathrm{m}$. obtain other rights in accordance with applicable laws and regulations.

Law no. 3 of 1997 on Juvenile Justice has required special treatment for the purpose of minimizing the negative impact of the criminal justice process, such as stigmatization and certain psychological distresses. These are all attempts by the government to protect the rights of juvenile inmates so that even in adulthood, adolescents do not lose their rights as human beings. Further, Heniarti (2017) states that although juvenile prisoners are in prisons, children's rights should not be neglected, since the imprisonment is a loss of the right to freedom only so that other rights must remain fulfilled.

\section{Social Anxiety In Juvenile Inmates And The Role Of Guidance And Counseling}

Prisoners undergoing criminal punishment in prisons, essentially having lost the freedom to interact with outside communities, can only interact in prison only and freedom is the most awaited period of inmate convicts (Faried \& Nashori, 2012). Once free, one of the inmates' barriers to engaging in social interaction is social anxiety, leading to excessive fear of criticism from others, and avoiding interaction with a group of people or social groups (Khurnia, 2013). Research conducted Faried \& Nashori (2012) finds anxiety facing the prisoner release period due to environmental factors and emotional cognitive factors. Social factors, because prisoners are afraid of being free do not get support from their families and also their environment, resulting in excessive fear of an uncertain condition. This is an important issue that needs to be addressed seriously by a counselor or coach of LPKA to reduce social anxieties of juvenile inmates when it is free.

The psychological assistance that can be done by fostering prison is through guidance and counseling services. Counseling and counseling become one of the most comprehensive needs nowadays in view of the growing human needs that are influenced by the philosophical factors of human nature, psychologically related to the process of development, the social culture of interaction between individuals, the advancement of science and technology, the democratization in education and the expansion of educational programs (Nurihsan, 2007: 1) that helps the individual in manifesting himself.

Counseling and guidance services are conducted in various areas of development, types of services and support activities in order to develop adolescent prisoners' ability to prepare for a better social life once free. Prayitno (2014), proposes guidance and counseling services referring to seven areas of development, ten types of counseling and guidance services and 
six forms of support activities. The ten types of counseling and guidance services are (1) orientation, ie services that help individuals to understand new environments to adapt and facilitate and smoothen the role of individuals in new environments; (2) information, ie services that help individuals receive and understand various information self, social, learning, career / occupation, and further education; (3) placement and channeling services, ie services that assist individuals in obtaining appropriate placements and disbursements in the various jobs / activities that are in accordance with their potential; (4) Content mastery, a service that helps individuals to master certain content, especially competencies and or habits that are useful in life in the family and society; (5) Individual counseling, ie services that assist individuals in alleviating their personal problems; (6) Group Guidance, ie services that assist individuals in personal development, social relations skills, learning activities, career / occupation, and decision making, and perform certain activities through group dynamics; (7) Group Counseling, ie services that assist individuals in discussing and eradicating personal problems through group dynamics; (8) Consultations, ie services that assist individuals and / or other parties in gaining insight, understanding, and ways that need to be implemented in handling individual conditions and or problems; (9) Mediation, a service that helps learners solve problems and improve relationships between them and (10) Advocacy, which is a service that helps the individual to fulfill the various rights violated by another person/organization in fulfillment. (Prayitno, 2014; Alizamar, 2016; Afdal, 2015). Counseling guidance on inmates (prisoners of youth) serves to overcome excessive fear inmates by fostering psychological preparedness and resilience when they are faced with conditions when they are in prison and after they leave (Fitria, 2012). Similarly, Yusri (2015) stated that in an effort to help the prisoners of prison correctional institutions are expected to make a policy in conducting a conducive coaching approach by providing $\mathrm{BK}$ services to the recruits of the recidivism for the development of personality and independence so that they can become useful individuals in the community and do not repeat the same mistake again. This indicates that BK services have an important role for inmates one of them in reducing the social anxiety of juvenile inmates.
Based on the types of services previously mentioned, in order to help juvenile inmates not experiencing social anxiety is through service (1) orientation services, where juvenile prisoners should be given a new environmental understanding of prisons so that they can adapt and facilitate and smoothen their role in new environments, (2) information services, concerning social anxiety issues, counselors can provide a variety of information that adds to the understanding and skills of prisoners in preventing and overcoming social anxiety. This can be done by providing information services with the topic of understanding of self-concept, who I am and other materials; (3) placement and delivery services, prison counselors/coaches can locate and provide appropriate delivery of certain jobs and/or exercises appropriate to the conditions of juvenile inmates allowing them not to experience anxieties including social anxiety; (4) Individual counseling, counselor/coach can help individuals to address individual issues discussed with face to face especially the anxieties faced by individuals before the liberation period, such as fear will not be accepted and other fears; (6) Counseling and Counseling Groups, counselors can use group dynamics to discuss topics and issues related to the preparation of juvenile prisoners facing exemption.

\section{CONCLUSIONS AND RECOMMENDATIONS}

The deviant behavior perpetrated by teenagers can result in a violation of the law so that it is imprisoned. Although a teenager is already in prison, it is possible that once free he will become a useful person in society later on. One of the problems that happened to juvenile inmates was social anxiety which resulted in juvenile inmates avoiding social interaction with society after free.

Social anxiety conditions that occur in juvenile inmates caused by teenagers have been so long there is no interaction with the outside community, and feel has been badly captured by the community. Inmates who experience this social anxiety need to improve socialization with others

One strategy that can be used to overcome the problems faced by juvenile 
inmates with guidance and counseling services. Counseling and counseling services may be media modules.

In this case, it is expected to coach prison/counselor can play an active role in reducing the social anxiety of juvenile inmates. coach prison/counselors can develop and develop programs and services to reduce the social anxiety of juvenile inmates appropriately and accordingly.

\section{REFERENCES}

Abdollahi, A., Talib, M. A., Mobarakeh, M. R. V., Momtaz, V., \& Mobarake, R. K. (2015). Body-esteem mediates the relationship between self-esteem and social anxiety : The moderating roles of weight and gender. Child Care in Practice, 1(1), 1-14. https://doi.org/10.1080/13575279.2015.1 054787

Afdal, A. (2015). Kolaboratif: Kerangka Kerja Konselor Masa Depan. Jurnal Konseling dan Pendidikan, 3(2), 1-7.

Afdal, A., Suya, M., Syamsu, S., \& Uman, U. (2015). Bimbingan Karir Kolaboratif dalam Pemantapan Perencanaan Karir Siswa SMA. Jurnal Konseling dan Pendidikan, 2(3), 1-7.

Alizamar. (2016). Teori Belajar dan Pembelajaran (Implementasi dalam Bimbingan Kelompok Belajar di Perguruan Tinggi) Yogyakarta: Media Akademi.

Aqib, Zainal. (2013). Konseling Kesehatan Mental. Bandung: Yrama Widya.

Bakalim, O. (2016). Self-Confident Approach in Coping with Stress and Social Appearance Anxiety of Turkish University Students : The Mediating Role of Body Appreciation. International Journal of Higher Education, $5(4)$, 134-143. https://doi.org/10.5430/ijhe.v5n4p134

Bandelow, B \& Stein, J. D. (2004). Social Anxiety Disorder. New York: Marcel Dekker, Inc.
Biggs, B. K., Vernberg, E. M., \& Wu, Y. P. (2012). Social Anxiety and Adolescents Friendships : The Role of Social Withdrawal. Jornal of Early Adolescence, 32(6), 803-823. https://doi.org/10.1177/02724316114261 45

Brown, M. A., \& Stopa, L. (2008). The Looming Maladaptive Style in Social Anxiety. Elsevier, 39, 57-64.

Chaplin, J. E. (2011). Kamus Lengkap Psikologi. Terjemahan oleh Kartini Kartono. Jakarta: Raja Grafindo Persada.

Carney, C. E., \& Edinger, J. D. (2010). Insomnia and Anxiety. New York: Springer.

Clark, D. A., \& Beck, A. T. (2010). Cognitive therapy of Anxiety Disorders. New York: The Guilford Press.

Damer, D. E., Latimer, K. M., \& Porter, S. H. (2010). The Journal for Specialists in Group Work " Build Your Social Confidence ": A Social Anxiety Group for College Students. The Journal for Specialists in Group Work, 35(1), 37-41. https://doi.org/10.1080/01933920903463 510

Faried, L., \& Nashori, F. (2012). Hubungan Antara Kontrol Diri Dan Kecemasan Menghadapi Masa Pembebasan Pada Narapidana Di Lembaga Pemasyarakatan Wirogunan Yogyakarta. Khazanah: Jurnal Mahasiswa, 5(2), 63-74.

Festa, C. C., \& Ginsburg, G. S. (2011). Parental and Peer Predictors of Social Anxiety in Youth. Child Psychiatry Hum Dev, 42(1), 291-306. https://doi.org/10.1007/s10578011-0215-8

Fitria R. F. (2012). Penerapan Bimbingan Konseling Individu dalam Upaya Menumbuhkan Sikap Percaya Diri Narapidana (Penelitian di Lapas Sukamiskin Bandung) (Doctoral dissertation, UIN Sunan Gunung Djati Bandung). 
Heniarti, D. D. (2017). Problematika Pemenuhan Hak Asasi Manusia (Ham) Anak Pidana di Lembaga Pemasyarakatan Anak. Syiar Hukum, 8(3), 234-254.

Kearney, A. C. (2005). Social Anxiety and Social Phobia in Youth. Las Veges, Nevada: Springer Science+ Business media, Inc.

Khurnia, I. (2013). Menurunkan Kecemasan Sosial melalui Pemaknaan Kisah Hidup. Psikologi, 40(1), 39-58.

Mawandha, H. G., \& Ekowarni, E. (2017). Terapi Kognitif Perilaku dan Kecemasan Menghadapi Prosedur Medis Pada Anak Penderita Leukemia. JIP: Jurnal Intervensi Psikologi, 1(1), 75-92.

Nainggolan, T. (2011). Hubungan Antara Kepercayaan Diri Dengan Kecemasan Sosial Pada Pengguna Napza: penelitian di balai kasih sayang parmadi siwi. Sosiokonsepsia, 16(2), 161-174.

Nurihsan, A.J. (2007). Bimbingan dan Konseling dalam Berbagai Latar Belakang Kehidupan. Bandung: PT Refika Aditama.

Nevid, J. S., Rathus, S. A., \& Greene, B. (2005). Psikologi Abnormal. Edisi ke Lima. Jilid 1. Jakarta: Erlangga.

Papalia, D. E., Olds, S.W., \& Feldman, R.D. (2009). Human Development. Jakarta: Salemba Humanika.

Peraturan Menteri Hukum dan Hak Asasi Manusia No. 18 tahun 2015 tentang Organisasi dan Tata Kerja Lembaga Pembinaan Khusus Anak.
Puspitawati, H. (2006). Pengaruh Faktor Keluarga, Lingkungan Teman dan Sekolah terhadap Kenakalan Pelajar di Sekolah Lanjutan Tingkat Atas (SLTA) di Kota Bogor.

Root, B. (2000). Understanding Panic and Other Anxiety Disorders. USA: University Press of Mississippi.

Sagalakova, O. A., Truevtsev, D. V, \& Sagalakov, A. M. (2016). Cognitive and Perceptual Selectivity and Target Regulation of Mental Activity in Personal Evaluation Situations of Social Anxiety Disorder. journal of environmental \& science education, 11(12), 5049-5057.

Santrock, J. W. (2007). Adolescence (Eleventh Edition). Terjemahan oleh Benedictine Widyasinta. Jakarta: Erlangga.

Sistem Database Pemasyarakatan. (2017). http://smslap.ditjenpas.go.id. (online). Diakses pada tanggal 11Oktober 2017.

Wittchen, H. U., \& Fehm, L. (2003). Epidemiology and natural course of social fears and social phobia. Acta Psychiatrica Scandinavica, 108(s417), 4-18.

Yousaf, S. (2015). The Relation between Selfesteem , Parenting Style and Social Anxiety in Girls. Journal of Education and Practice, 6(1), 140-143.

Yusri, F. (2015). Konsep Diri Warga Binaan Yang Berstatus Residivis Dan Pelayanan Bimbingan Konseling Yang Dibutuhkannya Di Lembaga Pemasyarakatan Klas II A Padang. Jurnal Educative: Journal of Educational Studies, 7(1), 27-32. 